\title{
ANALISIS METODE CHEATING PADA TES BERSKALA BESAR
}

\author{
${ }^{1)}$ Yance Manoppo, ${ }^{2)}$ Djemari Mardapi \\ ${ }^{1)}$ Universitas Pattimura, ${ }^{2}$ Universitas Negeri Yogyakarta \\ 1)molucanano@yahoo.com, ${ }^{2}$ djemarimardapi@gmail.com
}

\begin{abstract}
Abstrak
Penelitian ini bertujuan untuk mengetahui: (1) karakteristik butir soal Kimia Ujian Nasional berdasarkan teori tes klasik dan teori respon butir; (2) besarnya kecurangan yang terjadi dengan menggunakan Metode Angoff's B-index, Metode Pair1, Metode Pair2, Metode Modified Error Similarity Analysis (MESA) dan Metode G2; (3) metode yang lebih banyak mendeteksi adanya kecurangan dalam pelaksanaan UN Kimia tingkat SMA/MA Negeri tahun pelajaran 2011/2012 di Provinsi Maluku. Hasil analisis dengan pendekatan teori tes klasik menunjukkan $77,5 \%$ butir memiliki tingkat kesulitan butir berfungsi baik, $55 \%$ butir daya bedanya belum memenuhi syarat, dan $70 \%$ butir memiliki pengecoh berfungsi baik dengan indeks reliabilitas tes 0,772 . Analisis dengan pendekatan teori respons butir menunjukkan $14(35 \%)$ butir cocok dengan model, fungsi informasi maksimum 11,4069 pada $\theta=-1,6$, dan besarnya kesalahan pengukuran 2,296. Jumlah pasangan yang diduga curang adalah: menurut Metode Angoff's Bindex ada 13 pasangan, menurut Metode Pair1 ada 212 pasangan, menurut Metode Pair2 ada 444 pasangan, menurut Metode MESA ada 7 pasangan, dan menurut Metode G2 ada 102 pasangan. Metode yang paling banyak mendeteksi kecurangan secara berturut-turut adalah: Metode Pair2, Metode Pair1, Metode G2, Metode Angoff's B-index, dan Metode MESA.
\end{abstract}

Kata kunci: ujian nasional, karakteristik butir, metode kecurangan

\section{AN ANALYSIS OF METHOD OF CHEATING ON LARGE TEST SCALE}

\author{
${ }^{1)}$ Yance Manoppo, ${ }^{2}$ Djemari Mardapi \\ ${ }^{1)}$ Universitas Pattimura, ${ }^{2}$ Universitas Negeri Yogyakarta \\ 1)molucanano@yahoo.com, ${ }^{2}$ djemarimardapi@gmail.com
}

\begin{abstract}
This study aimed to reveal: (1) the characteristics of items of Chemistry Test in National Examination by using the classical test theory and item response theory; (2) the amount of cheating which occured by using Angoff's B-index Method, Pair 1 Method, Pair 2 Method, Modified Error Similarity Analysis (MESA) Method, and G2 Method; (3) the methods that detected more cheating in the implementation of the Chemistry Test in National Examination for high schools in the academic year 2011/2012 in Maluku Province. The results of the analysis with the classical test theory approach show that $77.5 \%$ items have item difficulty functioning well, 55\% items have discrimination that has not met the requirement yet, and $70 \%$ items have distractor that works well with the index reliability test of 0,772 . The analysis using the item response theory approach shows that $14(35 \%)$ items fit with the model, the maximum function information is 11,4069 at $\theta=-1,6$, and the magnitude of the error of measurement is 2,296. The number of pairs who are suspected of cheating is as follows: 13 pairs according to Angoff's B-index Method, 212 pairs according to Pair 1 Method, 444 pairs according to Pair 2 Method, 7 pairs according to MESA Method, and 102 pairs according to G2 Method. The most widely detecting cheating in a row is a Pair 2 Method, Pair 1 Method, G2 Method, Angoff's B-index Method, and MESA Method.
\end{abstract}

Keywords: national examination, items characteristics, methods of cheating 


\section{Pendahuluan}

Pendidikan nasional bertujuan untuk mengembangkan potensi peserta didik agar menjadi manusia yang beriman dan bertakwa kepada Tuhan Yang Maha Esa, berakhlak mulia, sehat, berilmu, cakap, kreatif, mandiri, dan menjadi warga negara yang demokratis serta bertanggung jawab. Tujuan tersebut tercantum dalam Undang-Undang Nomor 20 Tahun 2003 Bab 2 pasal 3 yang ditetapkan oleh Pemerintah Indonesia melalui Direktorat Jenderal Pendidikan Dasar dan Menengah Departemen Pendidikan dan Kebudayaan yang kemudian ditegaskan kembali dalam Peraturan Pemerintah Republik Indonesia Nomor 19 Tahun 2005 Bab 2 pasal 4, mengenai tujuan standar pendidikan nasional.

Ujian Nasional (UN) merupakan sistem evaluasi standar pendidikan dasar dan menengah secara nasional. UN dilakukan oleh Depdiknas (Undang-Undang Republik Indonesia Nomor 20 Tahun 2003). Evaluasi UN dilakukan oleh lembaga yang mandiri secara berkala, menyeluruh, transparan, dan sistematik untuk menilai pencapaian standar nasional pendidikan. Proses pemantauan evaluasi UN harus dilakukan secara berkesinambungan. Pelaksanaan UN diharapkan dapat dipetakan tingkat kemampuan sekolah sehingga dapat menentukan skala prioritas penanganan proses pendidikan. Kejujuran dan prestasi menjadi kata kunci dalam pelaksanaan UN. Untuk mengukur objektivitas, validitas, dan reliabilitas mutu hasil UN, dapat ditelusuri dengan mengembangkan metode analisis pola jawaban peserta ujian. Analisis pola jawaban dapat mengidentifikasi adanya intervensi dari luar atau ketidakjujuran peserta ujian dalam menjawab soal sewaktu penyelenggaraan UN. Salah satu teknik untuk mendeteksi kejujuran dalam pelaksanaan UN yaitu dengan melihat pola jawaban peserta ujian yang bersumber dari Badan Standar Nasional Pendidikan (BSNP).

Kenyataan bahwa sistem pendidikan Indonesia yang menggunakan nilai dari tes atau evaluasi belajar terhadap materi yang diberikan sebelumnya untuk menunjukkan kemajuan dan penguasaan ilmu anak didik, menyebabkan masyarakat memandang prestasi belajar hanya dari pencapaian nilai yang tinggi, bukan pada prosesnya. Pandangan tersebut menimbulkan tekanan pada siswa untuk mencapai nilai yang tinggi. Tekanan yang dirasakan akan membuat siswa lebih berorientasi pada perolehan nilai, bukan pada pemahaman ilmu. Siswa dapat mempersepsi ujian sebagai alat untuk menyusun peringkat dan dapat menyebabkan dirinya mengalami kegagalan, bukan sebagai instrumen yang dapat menunjukkan kemajuan dalam proses belajar.

Cheating (ketidakjujuran) pada tes biasanya sering terjadi di semua tingkat dan situasi tes, dari mulai tingkat kelas (Lim \& Sean, 2001; Einsenberg, 2004; William, 2002; Anderman, Griesinger \& Westerfild, 1998) sampai high school atau academic institution (Anderman, Cupp \& Lane, 2010; Storm \& Storm, 2007; Lama, 2008; Chula, Guyette \& Piotrowoski, 2009; Williams, Craig \& Paulhus, 2010; McCabe, Trevino \& Butterfield, 2001). Cheating berakibat buruk pada rasa keadilan dan kejujuran dari peserta tes serta dapat merusak tujuan tes tersebut di lakukan. Untuk high-stake assessments akibat dari ketidakjujuran ini sangat besar karena akan menurunkan tingkat kepercayaan masyarakat terhadap penyelenggaraan tes itu sendiri.

Perilaku cheating banyak diakibatkan oleh pengaruh kelompok yang orang cenderung berani melakukan karena melihat orang lain di kelompoknya juga melakukan. Apabila kecenderungan ini berlangsung secara terus-menerus, maka cheating akan menjadi kebiasaan seseorang, yang akan ditransfer tidak hanya pada kegiatan sekolah lainnya tetapi kepada kegiatan kemasyarakatan pada umumnya berdasarkan prinsip transfer of learning. Pada akhirnya, cheating akan menimbulkan kehancuran di masa mendatang. Hal ini sesuai dengan apa yang dinyatakan Cizek (2001, pp.3-4) sebagai berikut:

There are many forms of cheating that can occur on such tests. In general, cheating can be defined as any action that violates the rules for 
administering a test, any behavior that gives an examinee an unfair advantage over other examinees, or any action on the part of an examinee or test administrator that decreases the accuracy of the intended inferences arising from the examinee's test score or performance.

Berdasarkan pendapat Cizek tersebut, diperoleh bahwa kecurangan secara umum dapat didefinisikan sebagai perilaku yang menyalahi aturan dalam penyelenggaraan tes, perilaku apa pun yang memberikan peserta ujian keuntungan yang tidak wajar atas peserta ujian lainnya, atau tindakan lain dari penyelenggara ujian yang mengurangi keakuratan hasil dimaksud yang berasal dari skor tes atau kinerja peserta ujian.

Sementara Lewkowicz (2007, p.147) mengatakan bahwa :

Cheating, defined as "to full by trickery," is seen as behavior that seems to be based, at least partly, on several assumptions, including, "I don't have to work hard at school. I'll be lucky and win the lottery or become famous," and "I will never succeed so why bother to try," and "It is awful, and I must no accept myself until I measure up to everyone else.

Pendapat Lewkowicz menjelaskan bahwa kecurangan didefinisikan sebagai sesuatu yang penuh dengan tipu daya yang mengajarkan siswa tidak perlu belajar keras di sekolah atau siswa menganggap dirinya tidak akan berhasil jadi mengapa harus bersusah payah mencoba. Kondisi ini dapat menghilangkan rasa kepercayaan diri dari siswa untuk sama seperti teman-teman lainnya.

Permasalahan cheating merupakan masalah yang dihadapi oleh semua negara. cheating pada akhirnya menjadi perhatian internasional. Cheating sudah tidak asing lagi bagi pelajar dan mahasiswa (Bogle, 2000; Milliron \& Sandoe, 2008). Setiap orang pasti ingin mendapat nilai yang baik dalam ujian, dan sudah tentu berbagai macam cara dilakukan untuk mencapai tujuan itu. Masalah cheating selalu terkait dengan tes atau ujian.

Penelitian sebelumnya tentang cheating sering terfokus pada deskriptif isu-isu seperti gender dan perbedaan budaya. Sebagai contoh, Newstead et al. (Anderman, Griesi- nger \& Westerfield, 1998, pp.84-85) melaporkan bahwa di antara mahasiswa, pria melaporkan kecurangan lebih daripada wanita, siswa yang lebih muda melaporkan kecurangan lebih daripada siswa yang lebih tua, dan siswa kemampuan rendah melaporkan kecurangan lebih daripada kemampuan siswa yang lebih tinggi. Dalam internasional studi tentang kecurangan, Evans, Craig \& Mietzel (Anderman, Griesinger \& Westerfield, 1998, p.85) menemukan bahwa siswa dari berbagai negara ditafsirkan memiliki kecurangan dalam cara yang berbeda.

Perilaku cheating tidak hanya terjadi pada siswa di SMP atau SMA tetapi terjadi pula di bangku kuliah atau universitas. Storm \& Storm (2007, pp.105-106) menyatakan beberapa data yang memprihatinkan adalah survei nasional yang dilakukan oleh Josephson Institute of ethics di Amerika pada tahun 2006 dengan responden 36.000 siswa Sekolah Menegah Pertama menemukan 60\% siswa menerima dan mengakui pernah melakukan kecurangan pada saat ujian dan pengerjaan tugas. Terjadi peningkatan sebesar $1 \%$ dalam kurun waktu 2 tahun, 95\% di antaranya mengaku bahwa tidak pernah ketahuan ketika melakukan kecurangan. permasalahan ini dalam berbagai kajian dan penelitian perlu untuk segera mendapatkan penanganan.

Temuan hasil penelitian lain yang menarik adalah dari The Epoch Time 2005 yang mengambil data dari 90 mahasiswa. Dari jumlah tersebut, 83\% mengaku pernah cheating ketika pelaksanaan tes atau ujian. (Strom \& Strom, 2007, p.105). Selain itu, di China akhirnya diterapkan adanya sanksi bagi mahasiswa yang cheating akan dihukum dengan 7 tahun penjara. Menurut Callahan (Strom \& Storm, 2007, p.105), perilaku cheating juga ditemukan pada siswa di Australia, Inggris, India, Jepang, Korea, Spanyol, dan Skotlandia. Anderman, Griesinger \& Westerfield (1998: 84) menjelaskan bahwa menyontek merupakan hal yang biasa di kalangan remaja karena siswa sekolah lanjutan lebih berfokus pada peringkat dan performa dibandingkan dengan siswa sekolah dasar. Brades (Cizek, 1999, p.15) menemukan bahwa 65\% dari siswa sekolah 
dasar mengakui menyalin setidaknya sekali dari siswa lain selama dites.

Sementara itu Widiatmo (2009, p.219) menjelaskan bahwa untuk mengurangi kemungkinan peserta uji melakukan kecurangan, banyak usaha preventif yang dilakukan untuk mengurangi kesempatan peserta tes dalam melakukan cheating. Usaha-usaha tersebut antara lain dengan menambah proctors (pengawas tes) sehingga peserta uji dapat diawasi, dengan membagikan lebih dari satu paket tes, dan memperlebar jarak tempat duduk antarpeserta tes. Sebagai ilustrasi, American College Testing (ACT), sebuah lembaga testing ternama di United State of America, membagikan secara random 8 sampai 12 paket tes setiap kali tes dilaksanakan. Jika ada 30 peserta uji dalam satu ruangan dan ada 10 paket tes yang dibagikan, maka kemungkinan ada 3 orang yang akan memperoleh paket tes yang sama. Lebih lanjut, kemungkinan dua peserta uji yang duduk berdekatan memperoleh paket tes yang sama sangat kecil 0,01 (satu berbanding 100). Dengan usaha-usaha preventif seperti itu kemungkinan peserta uji melakukan kecurangan sangat kecil. Kenyataan lapangan membuktikan usaha-usaha preventif tersebut tidak efektif.

Faktor kemajuan teknologi juga memberikan kontribusi terhadap cheating pada jalannya UN di sekolah-sekolah. Menurut Aziz (2012, p.3) yang dimuat pada Tempo Online soal UN 2012 untuk Sekolah Menengah Pertama (SMP) di Kota Sukabumi, Jawa Barat, diduga bocor. Hal itu ditandai dengan beredarnya kunci jawaban di kalangan siswa melalui short message service (SMS) padahal pihak dinas pendidikan setempat menjamin UN di Kota Sukabumi tidak ada kebocoran. Dengan kecanggihan alat komunikasi, tentunya peristiwa yang sama dapat terjadi di setiap daerah yang telah terjangkau sarana komunikasi seluler ini.

Selain permasalahan bocornya tes, pencapaian kualitas soal sesuai dengan karakteristik butir tes yang baik sangat dipengaruhi sumber daya penyusun tes. Sebagaimana yang diketahui bersama, perangkat tes UN disusun dalam bentuk tes objektif de- ngan menggunakan multiple choice atau bentuk pilihan berganda. Tes seperti ini membutuhkan pemahaman yang komprehensif dan mendalam dari peserta UN sehingga mampu memberikan jawaban yang benar pula. Dengan demikian, perangkat tes harus memiliki kehandalan, kesahihan, daya pembeda, distraktor untuk mendeteksi kemampuan siswa secara objektif. Adanya perangkat tes yang kurang baik menyebabkan praktik-praktik cheating (kecurangan) lebih mudah dilakukan oleh karena kesulitan siswa dalam menjawab soal dengan benar disamping adanya tekanan untuk harus lulus dalam Ujian Nasional.

Berdasarkan uraian di atas maka yang dimaksud dengan cheating dalam tulisan ini adalah segala perbuatan atau trik-trik yang tidak jujur, perilaku tidak terpuji atau perbuatan curang yang dilakukan oleh seseorang untuk mencapai keberhasilan dalam menyelesaikan tugas-tugas akademik terutama yang terkait dengan evaluasi/ujian hasil dengan mengabaikan aturan dan kesepakatan yang ada. Perilaku cheating terjadi karena masyarakat memiliki pandangan bahwa prestasi belajar tercermin dari pencapaian nilai yang tinggi, sehingga membuat siswa terpaku untuk memperoleh nilai tinggi dengan cara apa pun. Masyarakat cenderung semakin permisif sehingga menyebabkan perilaku cheating semakin sulit dihilangkan. Fakta-fakta tersebut menunjukkan bahwa cheating merupakan suatu permasalahan yang menarik untuk dianalisis lebih lanjut. Untuk itu, melalui penelitian ini penulis akan meneliti beberapa metode yang dipakai untuk mendeteksi kemungkinan peserta ujian melakukan cheating atau sering diidentikkan dengan collusion dengan melihat pola respon jawaban dari peserta tes (examines). Oleh karena itu, penelitian ini bertujuan untuk mengetahui: (1) karakteristik butir soal Kimia Ujian Nasional berdasarkan teori tes klasik dan teori respon butir; (2) besarnya kecurangan yang terjadi dengan menggunakan Metode Angoff's B-index, Metode Pair1, Metode Pair2, Metode Modified Error Simila-rity Analysis (MESA) dan Metode G2; (3) metode yang lebih banyak mendeteksi 
adanya kecurangan dalam pelaksanaan UN Kimia tingkat SMA/MA Negeri tahun pelajaran 2011/2012 di Provinsi Maluku.

\section{Metode Penelitian}

Jenis Penelitian

Penelitian ini merupakan penelitian kuantitatif menggunakan pendekatan ex-post facto.

\section{Waktu dan Tempat Penelitian}

Penelitian ini dilakukan di Lab Komputer Pascasarjana Universitas Negeri Yogyakarta setelah memperoleh data respon sampel (LJK) dari Puspendik Kemdikbud Jakarta. Kegiatan penelitian ini dilaksanakan pada Maret 2013.

Target/Subjek Penelitian

Target dalam penelitian ini adalah perangkat tes UN Kimia tingkat SMA/MA Negeri tahun pelajaran 2011/2012 di Provinsi Maluku.

\section{Prosedur}

1. Menganalisis butir tes dengan perangkat lunak Iteman versi 3.0 untuk melihat karakteristik butir tes yang meliputi tingkat kesukaran butir, daya pembeda butir, dan statistik sebaran jawaban. Selain itu ditentukan juga kehandalan/reliabilitas tes, kesalahan pengukuran (SE) dan distribusi skor.

2. Menganalisis butir dengan pendekatan teori respons butir menggunakan program Bilog-MG 3.0. Dari analisis ini diperoleh parameter butir, parameter peserta, fungsi informasi tes, dan grafik informasi tes. Dari analisis ini diperoleh besarnya Fungsi Informasi maksimum tiap butir, dan skala kemampuan $\theta$ yang diambil antara -4,0 dan 4,0 dengan interval 0,25.

3. Menaksir kecocokan data dengan model dan parameter butir dengan program Bilog-MG 3,0. Kecocokan butir dengan model dapat dilihat dari harga $p$ yang muncul dari hasil analisis dengan program Bilog-MG. Untuk butir yang memiliki harga $p$ lebih kecil dari 0,01 dianggap tidak cocok dengan model logistik 2parameter.
4. Mendeteksi cheating dengan Metode Angoff's B-index, Metode Pair 1, Metode Pair 2, Metode MESA, dan Metode G2 dengan software Integrity ${ }^{\mathrm{TM}}$.

5. Menentukan keakuratan dari kelima metode deteksi cheating dengan melihat metode mana yang dapat mendeteksi cheating lebih banyak.

Data, Intrumen, dan Teknik Pengumpulan Data

Data yang digunakan dalam penelitian ini adalah respon peserta UN di Propinsi Maluku khususnya mata pelajaran kimia tingkat SMA/MA sekolah Negeri Paket soal C72 sebanyak 1620 siswa. Pengumpulan data dalam penelitian ini dilakukan dengan menggunakan teknik dokumentasi, yakni mengutip respon siswa (LJK) pada perangkat tes UN Kimia Paket C72 SMA/MA Negeri di Provinsi Maluku tingkat 2011/ 2012. Data-data berupa LJK diperoleh dari Puspendik Jakarta.

Teknik Analisis Data

Analisis Karakteristik Butir Soal

Analisis terhadap butir soal secara kuantitatif (empiris) menggunakan pendekatan teori tes klasik dan teori respon butir (IRT).

1. Analisis Empiris dengan Teori Tes Klasik a. Tingkat Kesukaran Butir Soal

Tingkat kesukaran butir dianlisis dengan menghitung proporsi menjawab benar $(p)$ sebuah butir soal. Apabila indeks $\mathrm{p}<0,30$ maka butir soal termasuk sukar, apabila $0,30 \leq \mathrm{p} \leq 0,70$ maka butir soal memiliki tingkat kesukaran yang sedang, jika $\mathrm{p}>0,70$ maka soal termasuk soal yang mudah. Akan tetapi oleh karena Ujian Nasional dikembangkan berdasarkan acuan kriteria (tidak membedakan) bukan acuan norma (dapat membedakan), maka besarnya tingkat kesukaran memberikan makna jika minimal 75\% (KKM= 75) siswanya bias menjawab butir dengan benar maka siswa tersebut dikatakan sudah "berbasil" atau dengan kata lain guru telah berhasil dalam mengajar.

Analisis Metode Cheating pada Tes Berskala Besar - 119

Yance Manopo, Djemari Mardapi 
Menurut Shapiro (2011, p.17) acuan criteria juga dapat digunakan dalam mencari sejauhmana permasalahan yang dihadapi siswa dalam belajar sehingga dapat dicari jalan keluarnya.

b. Daya Pembeda Butir Soal

Daya beda butir soal (item) adalah korelasi antara skor butir soal dengan skor total, dihitung dengan rumus korelasi point biserial. Besarnya daya beda butir soal untuk menyatakan bahwa butir soal baik adalah minimal 0,3. Sedangkan item soal dengan point biserial di bawah 0,3 termasuk item yang kurang baik.

c. Keberfungsian Pengecoh

Untuk mengetahui suatu pengecoh berfungsi secara baik dapat dilihat dari distribusi jawaban. Suatu pengecoh dapat dikatakan berfungsi baik jika paling sedikit pilihan jawaban dipilih oleh 5\% peserta tes. Beberapa literatur pada penelitian yang lain juga menyebutkan $2 \%$, tetapi sebenarnya jika ada yang menjawab saja sudah bisa dikategorikan bahwa pengecohnya (distractor) sudah berfungsi dengan baik.

d. Indeks Reliabilitas.

Nilai indeks reliabilitas tes dapat dilihat pada nilai koefisien alpha. Semakin besar nilai alpha menunjukkan semakin reliabel tes tersebut dan semakin kecil tingkat kesalahan pengukuran. Standar yang digunakan dalam penelitian ini adalah yang mensyaratkan instrumen yang reliabel haruslah memiliki koefisien reliabilitas minimal 0,7.

2. Analisis Empiris Butir dengan Teori Respon Butir

Analisis dengan program Bilog-MG menghasilkan output dalam bentuk tiga fase. Fase pertama merupakan estimasi butir berdasar teori klasik, fase kedua estimasi parameter butir berdasar Teori Respons Butir dan fase ketiga estimasi kemampuan peserta.

Pada fase pertama diperoleh informasi tentang banyaknya peserta tes yang menjawab benar, proporsi peluang menjawab benar dibagi peluang menjawab salah serta koefisien korelasi biserial. butir yang memiliki nilai koefisien biserial negatif dapat mengganggu proses analisis selanjutnya, sehingga butir tersebut tidak diikutkan dalam analisis berikutnya. Jumlah butir yang tidak diikutkan untuk tahap analisis selanjutnya terdiri dari 2 butir tes Kimia UN SMA/MA Paket C72 tahun pelajaran 2011/2012 Provinsi Maluku.

Fase kedua, estimasi parameter teori respon butir. Pada fase ini diperoleh tentang informasi parameter butir sesuai dengan model teori tespon butir yang digunakan. Selanjutnya, untuk model 1PL didapatkan estimasi tingkat kesukaran, model 2-PL diperoleh estimasi parameter berupa tingkat kesukaran dan daya beda, sedangkan model 3-PL didapatkan informasi tentang tingkat kesukaran, daya beda, dan tebakan semu. Selain parameter butir, pada fase kedua juga dihasilkan statistik kecocokan suatu butir dengan model atau goodness of fit statistic. Model yang digunakan untuk estimasi parameter adalah model logistik yang banyak menerima butir yang cocok.

Secara empiris, kualitas butir ditelaah berdasarkan kecocokan data dengan model dan nilai parameter butir. Kecocokan suatu butir dengan model dapat dilihat dari nilai chi kuadrat butir dibandingkan dengan harga kritik distribusi chi kuadrat sesuai dengan $d k$ butir yang bersangkutan pada taraf signifikansi $a$. Butir dikatakan tidak cocok model jika nilai $\chi^{2}$ butir lebih besar dari harga distribusi $\chi^{2}$ pada nilai kritisnya, sebaliknya butir cocok dengan model jika nilai $\chi^{2}$ item lebih kecil atau sama dengan nilai distribusi $\chi^{2}$. Atau dikatakan cocok model jika probabilitas $\chi^{2}$ lebih besar dari 0,01.

Berdasarkan perbandingan ketiga model parameter logistik untuk uji kecocokan model, maka model 2-PL pada umumnya lebih banyak menghasilkan butir yang fit (cocok). Untuk keseragaman model analisis, estimasi parameter butir untuk seluruh materi uji dianalisis menggunakan model 2-PL. 
Fase ketiga didapatkan estimasi parameter kemampuan peserta dan fungsi informasi tes. Pada penelitian ini informasi yang digunakan hanya fungsi informasi tes, sehingga estimasi parameter kemampuan peserta tidak dianalisis. Besarnya fungsi informasi tes dihitung menggunakan program Excel.

Berdasarkan kriteria di atas, untuk menentukan kualitas butir yang baik dengan pendekatan teori respon butir didasarkan pada kriteria: (1) butir cocok model, (2) mempunyai daya beda 0 sam-pai 2, dan (3) tingkat kesulitan -2 hingga +2 (Hambleton \& Swaminathan, 1985, p.36).

\section{Analisis Cheating}

Selanjutnya, untuk mendeteksi adanya cheating maka digunakan software Integrity ${ }^{T M}$. Software ini adalah sebuah aplikasi interface online yang aman dan dirancang untuk menganalisis data ujian pilihan ganda. Program ini mengevaluasi statistik kejujuran suatu tes dan kejujuran akademik siswa yang mengikuti tes. Integrity menggunakan file data yang dikirimkan oleh pengguna (client) untuk mendapatkan informasi statistik uji secara rinci, serta laporan statistik deteksi penyalinan jawaban secara rinci.

\section{Hasil Penelitian dan Pembahasan}

Karakteristik Butir Tes Klasik dengan Program Iteman

\section{Statistik Butir Soal}

Pada tampilan hasil statistik butir soal dapat diketahui hasilnya untuk soal yang dikategorikan sukar atau tidak mencapai keberhasilan 4 butir, kategori kurang berhasil 5 butir, dan yang mencapai keberhasilan 31 butir. Soal yang memiliki daya beda yang baik 22 butir, tidak baik 18 butir sedangkan untuk pengecoh 28 butir yang tergolong baik.

\section{Statistik Tes/Skala}

Berdasarkan statistik hasil analisis program Microcat Iteman versi 3.0 terhadap 40 butir soal Kimia UN Paket C72 tingkat SMA/MA tahun pelajaran 2011/2012 yang direspon oleh peserta ujian sebanyak 1620 orang pada Tabel 1 dapat bahwa peserta rata-rata dapat menjawab dengan benar sebesar 31 butir soal (mean $=30,981$ ), berarti rata-rata lebih dari setengah $(75 \%)$ dari jumlah butir soal dapat dijawab dengan benar oleh peserta ujian, skor tertinggi 38 dan terendah 6. Nilai rerata $(30,981)$ yang berdekatan dengan nilai median $(32,00)$. Ratarata tingkat kesukaran butir soal pada umumnya sedang (mean $p=0,775$ ), cenderung banyak pada kisaran indeks 0,30 sampai 0,70 . Butir soal cukup mampu membedakan kelompok siswa berkemampuan tinggi dengan kelompok siswa berkemampuan rendah, hal tersebut dinyatakan oleh rerata indeks daya pembeda 0,331 .

Indeks reliabilitas soal 0,772 dapat dinyatakan baik, artinya $77,2 \%$ perbedaan skor yang terdapat pada peserta ujian adalah kemampuan yang sebenarnya, sedangkan $22,8 \%$ perbedaan skor yang ada merupakan kesalahan pengukuran. Menurut Linn (Mardapi, 1999, p.14), kesalahan pengukuran bisa disebabkan oleh variasi acak dalam diri manusia, faktor lingkungan, subjektivitas pengukur, dan alat ukur. Kesalahan baku pengukuran pada perangkat soal hasil analisis secara klasik adalah sebesar 2,209.

Tabel 1. Karakteristik Tes Kimia UN Paket 72 Tahun Pelajaran 2011/2012 dengan Program Iteman

\begin{tabular}{lc}
\hline \multicolumn{1}{c}{ Karakteristik } & Nilai \\
\hline Nof Item & 40 \\
N of Examinees & 1620 \\
Mean & 30,981 \\
Variance & 21,441 \\
Std. Dev. & 4,630 \\
Skew & $-1,776$ \\
Kurtosis & 4,593 \\
Minimum & 6,000 \\
Maximum & 38,000 \\
Median & 32,000 \\
Alpha & 0,772 \\
SEM & 2,209 \\
Mean P & 0,775 \\
Mean Item-Tot. & 0,331 \\
Mean Biserial & 0,527 \\
\hline
\end{tabular}

Analisis Metode Cheating pada Tes Berskala Besar - 121 Yance Manopo, Djemari Mardapi 
Berdasarkan Tabel 1, rerata tingkat kesulitan dan daya pembeda soal yaitu 0,775 dan 0,331 artinya soal tes ini rata-rata dijawab dengan benar butirnya sebesar 77,5\% atau dengan kata lain apabila dengan Kriteria Ketuntasan Minimal (KKM) sebesar 75 maka dapat ditafsirkan bawa tingkat keberhasilan guru dalam melaksanakan proses pembelajaran sudah berhasil, serta soal dapat membedakan siswa yang berkemampuan tinggi dan berkemampuan rendah sebesar 33,1\%. Hasil analisis soal Kimia UN Paket C72 menunjukkan bahwa tes tersebut memiliki reliabilitas yang baik yaitu di atas 0,70 . Kesalahan pengukuran dapat disebabkan oleh beberapa faktor, seperti lingkungan ketika ujian yang kurang mendukung, kondisi psikologis maupun biologis peserta tes atau terjadi kecurangan ketika pelaksanaan ujian seperti saling kerja sama antara peserta atau adanya bocoran kunci jawaban.

Berdasarkan analisis pogram Iteman, soal UN Kimia Paket C72 memiliki kualitas baik, karena $31(77,5 \%)$ butir soal memenuhi kriteria dan $9(22,5 \%)$ butir soal yang tidak memenuhi kriteria. Hal ini didukung juga dengan $70 \%$ pengecoh bekerja dengan baik meskipun dari kategori daya beda hanya 55\%. Hasil temuan dari 18 butir tersebut terdapat 2 butir soal dengan tanda "check the key" dari print out program Iteman, yaitu butir soal nomor 21 dan 39. Tanda tersebut merupakan suatu peringatan bagi pembuat soal untuk melihat kembali pada pilihan jawaban apakah sudah tepat atau belum. Selanjutnya, dari 40 butir soal Kimia Paket soal C72 yang diujikan secara nasional tahun pelajaran 2011/2012 di Provinsi Maluku ditemukan 9 butir soal yang perlu diperiksa kembali sebelum digunakan. Dengan demikian, berdasarkan kriteria yang telah ditetapkan dalam penentuan penerimaan butir soal, maka butir soal yang tidak sesuai dengan teori tes klasik adalah sebanyak $5(12,5 \%)$ butir perlu direvisi dan 4 $(10 \%)$ butir perlu diganti.

Karakteristik Butir Soal berdasarkan Pendekatan IRT

Pada analisis fase pertama, nilai biserial digunakan untuk menentukan apakah suatu butir diikutkan pada analisis berikutnya atau tidak. Fase pertama hasil output Bilog- $M G$ menunjukan bahwa dari 40 butir yang dianalisis terdapat 16 butir soal dengan kategori yang tidak baik atau sukar (butir soal nomor 3,21, 22, 33, 36, 39) sedangkan sisanya adalah berada pada kategori sedang dan mudah. Berdasarkan daya beda butir tes terdapat 16 butir soal dengan kategori tidak baik (butir soal nomor 3, 9, 11, 14, 18, 19, 21, 22, 26, 27, 28, 33, 36, 38, 39 40), dan 24 butir soal berkategori baik (butir soal nomor $1,2,4,5,6,7,8,10,12,13,15,16$, $17,20,23,24,25,29,30,31,32,34,35,37)$. Dalam konteks UN yang beracuan kriteria (criterion referenced test(CRT)) butir soal dengan tingkat kesulitan mudah dapat digunakan.

Butir soal yang tidak diikutkan dalam fase pertama disajikan pada Tabel 2 .

Tabel 2. Butir Hasil Analisis Bilog Fase Pertama yang Tidak Dapat Dilanjutkan ke Fase Kedua

\begin{tabular}{ccc}
\hline No & $\begin{array}{c}\text { Correlation } \\
\text { Biserial }\end{array}$ & Keterangan \\
\hline 3 & 0,062 & Tidak Dilanjutkan \\
9 & 0,208 & Tidak Dilanjutkan \\
11 & 0,263 & Tidak Dilanjutkan \\
14 & 0,268 & Tidak Dilanjutkan \\
18 & 0,234 & Tidak Dilanjutkan \\
19 & 0,281 & Tidak Dilanjutkan \\
21 & 0,042 & Tidak Dilanjutkan \\
22 & 0,08 & Tidak Dilanjutkan \\
26 & 0,246 & Tidak Dilanjutkan \\
27 & 0,271 & Tidak Dilanjutkan \\
28 & 0,287 & Tidak Dilanjutkan \\
33 & $-0,032$ & Tidak Dilanjutkan \\
36 & 0,12 & Tidak Dilanjutkan \\
38 & 0,249 & Tidak Dilanjutkan \\
39 & $-0,044$ & Tidak Dilanjutkan \\
40 & 0,2 & Tidak Dilanjutkan \\
\hline
\end{tabular}

Suatu butir dengan biserial kurang dari 0,3 tidak diikutkan pada analisis berikutnya, karena akan mengganggu proses analisis 
yakni munculnya nilai negatif yang tidak signifikan sehingga akan menimbulkan keputusan bias. Keputusan bias yang terjadi akan cenderung menolak butir pada sampel yang besar dan menerima butir pada sampel yang kecil. Menarik jika diperhatikan butir dengan biserial pada output tersebut yang memiliki nilai negatif dimana setelah dikorelasikan dengan bentuk butir pertanyaan, ternyata opsi jawaban yang diberikan memberikan sedikit kebingungan bagi siswa dalam menjawab oleh karena terlalu sulit dibedakan butir jawabannya.

Pada fase kedua hasil analisis model teori respons-butir dapat dikemukakan bahwa dari 24 butir soal yang dianalisis terdapat 14 butir soal yang baik atau $35 \%$ dan 10 butir soal yang tidak baik atau 25\%. Butir soal yang baik adalah butir soal dengan tingkat kesukaran soal $\left(b_{i}\right)$ terletak antara ($2,2)$, daya pembeda soal $\left(a_{i}\right)$ terletak antara $(0,2)$.

Hasil analisis estimasi parameter butir soal UN Kimia paket C72 SMA/MA menggunakan model 2-PL. Hasilnya, jumlah butir soal kimia yang layak dianalisis menggunakan IRT adalah sebanyak 24 butir. Rerata tingkat kesukaran soal kimia ditunjukkan oleh indeks -2,150 yang cenderung mengarah ke soal dengan kategori yang mudah. Rerata daya pembeda ditunjukkan oleh indeks 0,807 yang berarti memiliki daya pembeda yang kurang baik.

Pada Tabel 3 diperoleh informasi bahwa seluruh butir yang dianalisis lanjut ke fase kedua terdapat butir cocok dengan model 2-PL yang berjumlah 19 butir dengan memiliki nilai parameter daya pembeda berada pada interval 0 sampai 2. Informasi ini berarti kurang dari setengah dari keseluruhan butir soal Kimia UN paket C72 memiliki cukup kemampuan untuk membedakan tingkat kemampuan peserta ujian.

Hasil estimasi parameter tingkat kesukaran menunjukkan terdapat 15 butir yang berada pada interval -2 sampai 2, yang berarti memiliki tingkat kesukaran yang baik. Sebanyak 9 butir soal memiliki indeks kesukaran dibawah -2,0, sehingga dapat dikatakan sebagai butir yang mudah.
Tabel 3. Karakteristik Butir Soal UN Kimia Paket C72 dengan IRT

\begin{tabular}{|c|c|c|c|c|}
\hline Butir & $a$ & $b$ & $\begin{array}{c}\text { Kecocokan } \\
\text { model }\end{array}$ & Ket \\
\hline 1 & 0,468 & $-1,910$ & Cocok & Baik \\
\hline 2 & 0,492 & $-4,105$ & TC & TB \\
\hline 4 & 0,727 & $-2,689$ & Cocok & TB \\
\hline 5 & 0,716 & $-2,474$ & Cocok & TB \\
\hline 6 & 0,572 & $-2,863$ & Cocok & TB \\
\hline 7 & 0,587 & $-3,432$ & TC & TB \\
\hline 8 & 1,174 & $-1,596$ & Cocok & Baik \\
\hline 10 & 0,808 & $-1,990$ & Cocok & Baik \\
\hline 12 & 0,805 & $-1,040$ & Cocok & Baik \\
\hline 13 & 0,792 & $-1,628$ & Cocok & Baik \\
\hline 15 & 0,409 & $-3,551$ & $\mathrm{TC}$ & TB \\
\hline 16 & 0,763 & $-1,912$ & Cocok & Baik \\
\hline 17 & 0,978 & $-1,694$ & Cocok & Baik \\
\hline 20 & 0,887 & $-1,947$ & Cocok & Baik \\
\hline 23 & 0,764 & $-1,896$ & Cocok & Baik \\
\hline 24 & 1,279 & $-1,250$ & $\mathrm{TC}$ & $\mathrm{TB}$ \\
\hline 25 & 0,592 & $-1,883$ & Cocok & Baik \\
\hline 29 & 1,417 & $-1,749$ & Cocok & Baik \\
\hline 30 & 1,035 & $-1,893$ & Cocok & Baik \\
\hline 31 & 1,280 & $-1,273$ & Cocok & Baik \\
\hline 32 & 0,507 & $-2,387$ & Cocok & TB \\
\hline 34 & 1,056 & $-1,827$ & Cocok & Baik \\
\hline 35 & 0,548 & $-2,146$ & Cocok & TB \\
\hline 37 & 0,703 & $-2,458$ & TC & TB \\
\hline
\end{tabular}

Keterangan : $\mathrm{TC}=$ Tidak Cocok, $\mathrm{TB}=$ Tidak Baik

Hasil estimasi parameter di atas dapat dijadikan informasi untuk menentukan karakteristik butir yang baik. Butir yang baik hendaknya memenuhi 3 persyaratan yaitu, butir cocok model, mempunyai daya beda 0 sampai 2, dan tingkat kesulitan -2 sampai +2 . Berdasarkan kriteria tersebut maka dapat dikatakan bahwa untuk memilih soal yang baik terdapat 14 butir atau 35\% butir soal yang memenuhi persyaratan sebagai butir yang baik. Butir soal tersebut adalah butir nomor 1, 8, 10, 12, 13, 16, 17, 20, 23, 25, 29, 30, 31, dan 40 .

Analisis Metode Cheating pada Tes Berskala Besar - 123 
Estimasi parameter butir dengan model 2 parameter logistik pada tes Kimia UN paket C72, menghasilkan nilai informasi tes sebesar 11,4069 dengan tingkat kesalahan pengukuran 0,2961 . Nilai tersebut tercapai jika parameter kemampuan siswa
( $\theta$ ) sebesar $-1,60$. Perhitungan fungsi informasi tes dihitung dengan bantuan program Excel 2007 for windows. Grafik nilai fungsi informasi tes dengan parameter kemampuan peserta yang sesuai disajikan pada Gambar 1.

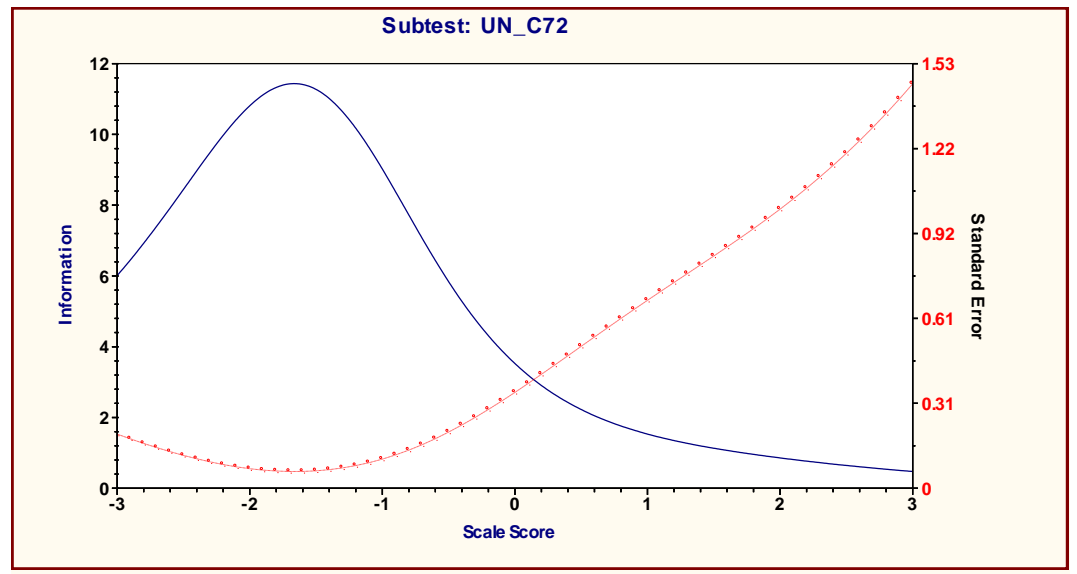

Gambar 1. Grafik Nilai Fungsi Informasi, Sekor Kemampuan dan Kesalahan Baku

Kesalahan pengukuran perangkat UN Kimia Paket C72 tingkat SMA/MA Negeri tahun pelajaran 2011/2012 di Provinsi Maluku berdasarkan hasil analisis menunjukkan bahwa besarnya kesalahan pengukuran sebesar 0,296. Kesalahan pengukuran dipergunakan untuk memahami kesalahan yang bersifat acak yang mempengaruhi skor peserta yang sebenarnya dalam pelaksanaan tes. Hasil perhitungan kesalahan pengukuran, diperoleh kesalahan pengukuran sebesar 0,296 dan skor maksimum yang dapat dicapai oleh peserta adalah 38, maka skor peserta UN Kimia Paket C72 tingkat SMA/ MA tahun pelajaran 2011/2012 di Provinsi Maluku sebenarnya berkisar pada $X_{i} \pm 0,296$.

\section{Analisis Cheating}

Deteksi cheating dalam penelitian ini menggunakan lima metode antara lain metode Angoff's B-index, metode Pair 1, metode Pair 2, metode MESA dan metode G2.

Hasil keseluruhan cheating untuk kelompok kota dapat dilihat pada Tabel 4 yang menyajikan frekuensi cheating masing-masing metode pada pelaksanaan UN Kimia SMA/ MA untuk paket tes $\mathrm{C} 72$ berdasarkan tiga kategori tingkat cheating yakni tinggi, sedang dan rendah. Metode Pair 2 yang memiliki frekuensi terbanyak dalam cheating ini setelah metode Pair 1 dan G2 sedangkan metode $B$ Index dan MES $A$ tidak ada pasangan yang didapati melakukan cheating. Besarnya frekuensi kasus cheating pada metode Pair 2 menerangkan bahwa terdapat sebanyak 52 pasangan yang terindikasi melakukan cheating dengan model jumlah soal terbanyak yang memiliki jawaban yang sama pada soal-soal berurutan. Sebanyak 14 pasangan memiliki intensitas melakukan kecurangan yang tinggi diikuti 15 pasangan pada level sedang sedangkan sisanya sebanyak 23 pasangan pada level yang rendah. Adanya kemungkinan penyebaran kunci jawaban pada sekolahsekolah di kota Ambon dibandingkan pada kota Tual juga sangat besar hal ini dapat dilihat pada tingginya frekuensi dari data benchmark group pada Tabel 5.

Tabel 4. Hasil Cheating pada Kelompok Kota (Ambon dan Tual) Berdasarkan Kedekatan Tempat Duduk

\begin{tabular}{lccccc}
\hline \multirow{2}{*}{ Kategori } & \multicolumn{5}{c}{ Metode Cheating } \\
\cline { 2 - 6 } & B-Index & Pair 1 & Pair 2 & MESA & G2 \\
\hline Tinggi & 0 & 0 & 14 & 0 & 0 \\
Sedang & 0 & 1 & 15 & 0 & 1 \\
Rendah & 0 & 6 & 23 & 0 & 4 \\
\hline Jumlah & 0 & 7 & 52 & 0 & 5 \\
\hline
\end{tabular}


Tabel 5. Hasil Cheating pada Kelompok Kota Ambon Berdasarkan Benchmark Group

\begin{tabular}{lccccc}
\hline \multirow{2}{*}{ Kategori } & \multicolumn{5}{c}{ Metode Cheating } \\
\cline { 2 - 6 } & B-Index & Pair 1 & Pair 2 & MESA & G2 \\
\hline Tinggi & 0 & 0 & 4 & 0 & 0 \\
Sedang & 0 & 0 & 159 & 0 & 0 \\
Rendah & 0 & 3 & 14 & 0 & 1 \\
\hline Jumlah & $\mathbf{0}$ & $\mathbf{3}$ & $\mathbf{1 7 7}$ & $\mathbf{0}$ & $\mathbf{1}$ \\
\hline
\end{tabular}

Data benchmark group pada Tabel 5 menjelaskan bahwa sebanyak 177 pasangan pada sekolah-sekolah yang tersebar di kota
Ambon memiliki jawaban yang seragam yang mengindikasikan kemungkinan terjadi penyebaran kunci jawaban. Hasil analisis cheating pada pelaksanaan UN Kimia SMA/ MA Negeri Paket tes C72 di Provinsi Maluku untuk kelompok kota dengan memperhitungkan keseluruhan pasangan yang diduga melakukan cheating dengan pasangan terdekat atau yang termasuk dalam benchmark group adalah berjumlah 16 pasangan pada metode Pair 1, 239 pasangan pada metode Pair 2, 6 pasangan untuk metode G2, sedangkan untuk metode Angoff's Bindex dan metode $M E S A$ tidak terdapat pasangan yang melakukan cheating.

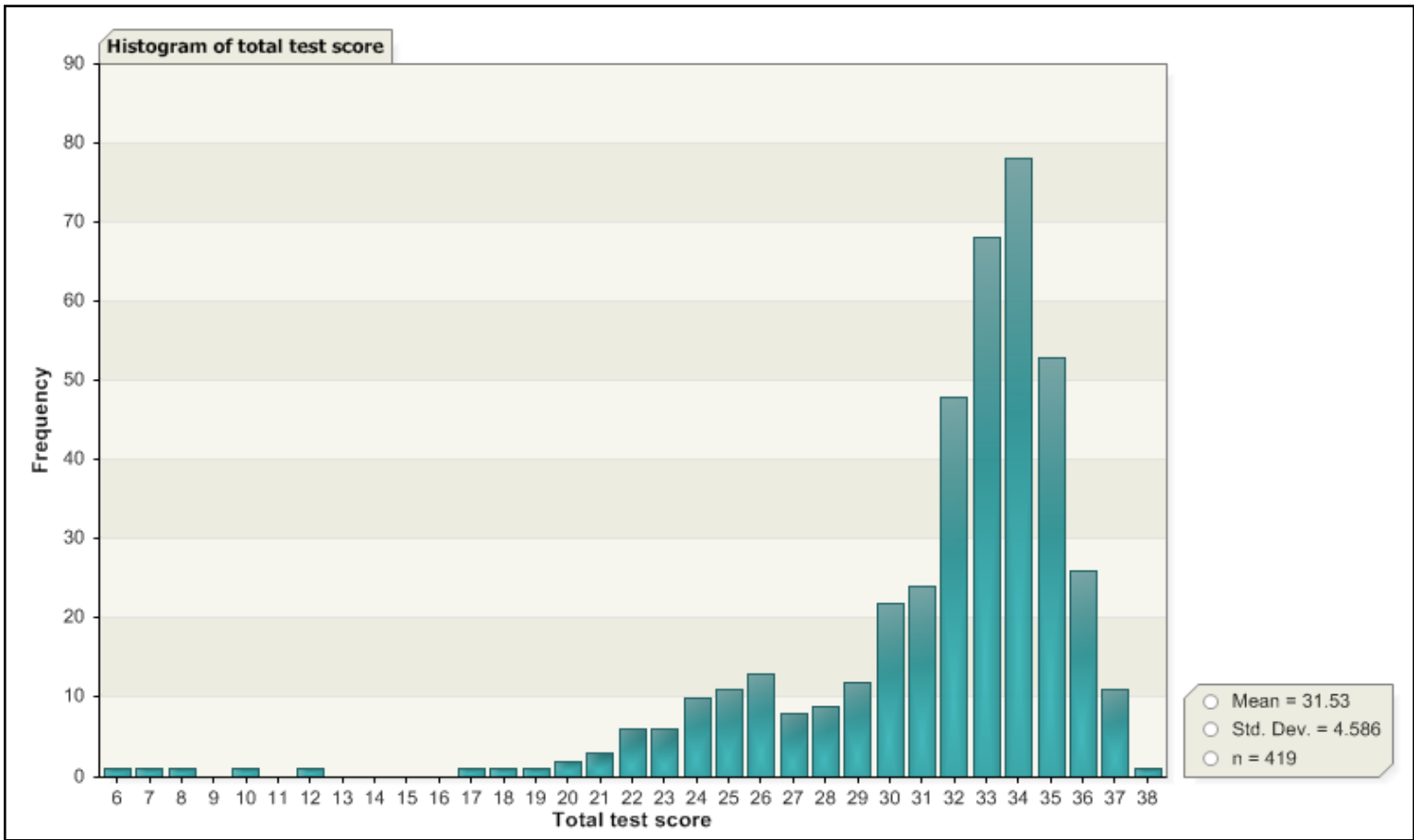

Gambar 2. Grafik Total Sekor Tes Peserta untuk Kota Ambon

Gambar 2 memperlihatkan histogram dari total skor tes pada salah satu kelompok kota yakni kota Ambon diperoleh skor ratarata (mean) sebesar 31,53 yang menunjukkan rata-rata peserta tes memiliki kemampuan yang tinggi dengan kemampuan menjawab soal cukup baik.

Cheating yang terjadi pada beberapa pasangan peserta tes membuktikan bahwa tidak semua peserta mampu menjawab dengan kemampuannya sendiri tetapi kemungkinan diduga terjadi kecurangan sewaktu pelaksanaan UN.
Hasil analisis cheating untuk daerah luar kota yang meliputi 9 Kabupaten yakni Kabupaten Maluku Tengah, Buru, Buru Selatan, Maluku Tenggara Barat, Maluku Barat Daya, Maluku Tenggara, Seram Bagian Barat, Seram Bagian Timur dan Kepulauan Aru. Tabel 6 menyajikan frekuensi cheating masing-masing metode pada pelaksanaan UN Kimia SMA/MA untuk Paket tes C72 pada daerah diluar kota dengan frekuensi terbesar pada metode Pair 2 sebanyak 392 pasangan diikuti dengan metode Pair 1 sebanyak 205 pasangan, metode $G 2$ sebanyak 
97 pasangan, metode B-Index sebanyak 13 dan metode $M E S A$ sebanyak 7 pasangan.

Tabel 6. Hasil Cheating pada Kelompok Luar Kota Berdasarkan Kedekatan Tempat Duduk

\begin{tabular}{lccccc}
\hline \multirow{2}{*}{ Kategori } & \multicolumn{5}{c}{ Metode Cheating } \\
\cline { 2 - 6 } & B-Index & Pair 1 & Pair 2 & MESA & G2 \\
\hline Tinggi & 0 & 0 & 245 & 0 & 11 \\
Sedang & 0 & 55 & 53 & 1 & 60 \\
Rendah & 13 & 150 & 94 & 6 & 26 \\
\hline Jumlah & $\mathbf{1 3}$ & $\mathbf{2 0 5}$ & $\mathbf{3 9 2}$ & $\mathbf{7}$ & $\mathbf{9 7}$ \\
\hline
\end{tabular}

Tabel 6 memberikan informasi bahwa kategori cheating tertinggi dalam metode Pair 2 yang mengindikasikan sebanyak 245 pasangan kemungkinan melakukan cheating sangat besar sekali dengan memperhatikan jumlah soal terbanyak yang memiliki jawaban yang sama pada soal-soal berurutan. Sebanyak sedangkan metode Pair 1 yang mengindikasikan tingkat penyalinan jawaban pada pasangan terdekat tergolong sedang dan rendah. Sementara metode G2 yang mendasarkan pada jumlah jawaban yang benar dan jumlah jawaban yang salah hasil salinan pada pasangan yang terlibat cheating. Hasilnya sebanyak 97 pasangan yang terlibat cheating untuk metode ini.

Metode B-Index membandingkan jumlah jawaban salah untuk semua pasangan peserta ujian yang masuk dalam interval sama dari hasil tes. interval ini didasarkan pada perkalian jumlah jawaban yang salah untuk sepasang peserta ujian kemudian diamati apakah signifikan berbeda dari nilai rata-rata jawaban salah untuk semua peserta ujian pada interval itu. Frekuensi yang terdeteksi melalui metode ini adalah sebanyak 13 pasangan dengan kategori yang rendah. Selain metode yang sudah disampaikan di atas terdapat metode MESA yang mendeteksi sebanyak 7 pasangan yang terlibat cheating dengan 1 pasangan pada kategori sedang dan 6 pasangan pada kategori rendah. Hal ini mengindikasikan bahwa probabilitas pasangan yang memiliki jawaban yang sama tetapi salah terdapat pada 7 pasangan tersebut.
Tabel 7. Hasil Cheating pada Kelompok Luar Kota Berdasarkan Benchmark. Group

\begin{tabular}{lccccc}
\hline \multirow{2}{*}{ Kategori } & \multicolumn{5}{c}{ Metode Cheating } \\
\cline { 2 - 6 } & B-Index & Pair 1 & Pair 2 & MESA & G2 \\
\hline Tinggi & 0 & 0 & 352 & 0 & 0 \\
Sedang & 0 & 76 & 64 & 0 & 93 \\
Rendah & 3 & 199 & 109 & 3 & 20 \\
\hline Jumlah & $\mathbf{3}$ & $\mathbf{2 7 5}$ & $\mathbf{5 2 5}$ & $\mathbf{3}$ & $\mathbf{1 1 3}$ \\
\hline
\end{tabular}

Selanjutnya, kemungkinan terjadi penyebaran jawaban pada 9 kabupaten (luar kota), maka Tabel 7 menjelaskan dengan frekuensi yang berbeda-beda yang dilihat berdasarkan data Benchmark Group, metode Pair 2, Pair 1, G2, B-Index dan MESA menunjukkan menunjukkan frekuensi indikasi penyebaran jawaban sangat besar. Hasil analisis cheating pada pelaksanaan UN Kimia SMA/MA Negeri Paket C72 tahun pelajaran 2011/2012 di Provinsi Maluku untuk kelompok luar kota (kabupaten) dengan memperhitungkan keseluruhan pasangan yang diduga melakukan cheating dengan pasangan terdekat atau yang termasuk dalam benchmark group adalah terdapat 16 pasangan untuk metode Angoff's B-index, 480 pasangan untuk metode Pair 1, 917 pasangan untuk metode Pair 2, 10 pasangan untuk metode $M E S A$, dan 210 pasangan untuk metode G2.

Secara keseluruhan untuk kelompok kota dan luar kota berdasarkan analisis metode cheating ditampilkan pada Gambar 3. Dari grafik tersebut ditampilkan terdapat jumlah pasangan yang diduga melakukan cheating untuk metode Angoff's B-index terdapat 13 pasangan, metode Pair 1 terdapat 212 pasangan, metode Pair 2 terdapat 444 pasangan, metode $M E S A$ terdapat 7 pasangan, dan metode $G 2$ terdapat 102 pasangan. Pasangan yang diambil adalah pasangan yang duduknya paling berdekatan sehingga adanya indikasi terjadinya cheating. Selanjutnya, bagi pasangan yang terindikasi cheating tetapi pada lokasi tempat duduk yang sudah berjauhan, pasangan ini dimasukkan ke dalam kelompok benchmark group untuk menduga terjadinya kebocoran atau penyebaran kunci jawaban pada sekolah maupun pada daerah tersebut. 


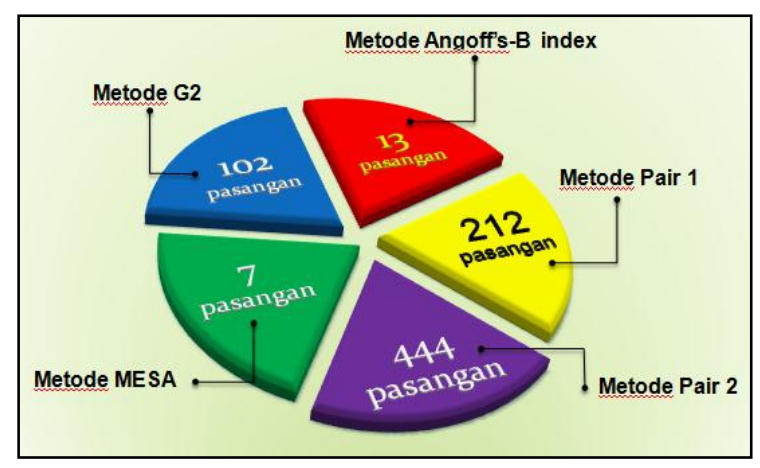

Gambar 3. Grafik Pasangan yang Terindikasi Cheating pada UN SMA/ MA Kimia Paket C72 Tahun Pelajaran 2011/2012 di Provinsi Maluku

Ketidakjujuran siswa menghadapi UN memupuk ketidak jujuran siswa menghadapi kehidupan bermasyarakat, yang pada akhirnya akan melahirkan generasi-generasi muda yang tidak jujur. Ironisnya adanya kemungkinan terjadinya cheating pada UN 2011/ 2012 ini yang kemungkinan terjadi penyontekan jawaban dan penyebaran jawaban oleh pihak-pihak sekolah (bahkan pemerintah daerah) mengizinkan (bahkan membantu) cheating tersebut berlangsung sebagai tujuan agar kelulusannya mencapai 100\%.

Akar permasalahan dari cheating UN menurut peneliti adalah UN sebagai alat untuk menentukan kelulusan yang hanya di administrasikan satu kali dalam setahun. Pihak-pihak tertentu (siswa, guru, kepala sekolah, orang tua, atau kepala daerah) yang merasa tidak siap menghadapi kemungkinan siswa-siswinya tidak lulus akan tergoda untuk melakukan kecurangan.

\section{Simpulan dan Saran}

Simpulan

Berdasarkan hasil penelitian dan pembahasan pada perangkat Ujian Nasional Kimia Paket C72 tingkat SMA/MA Negeri tahun pelajaran 2011/2012 di Provinsi Maluku dapat disimpulkan sebagai berikut: (1) berdasarkan pendekatan teori tes klasik terdapat $77,5 \%$ butir memiliki tingkat kesulitan butir berfungsi baik, $55 \%$ butir daya bedanya belum memenuhi syarat dan $70 \%$ butir pengecoh (distractor) berfungsi baik dengan indeks reliabilitas tes 0,772 ; (2) berdasarkan pendekatan teori respons butir terdapat 14 (35\%) butir soal cocok (fit) dengan model, fungsi informasi maksimum 11,4069 pada $\theta$ $=-1,6$, dan besarnya kesalahan pengukuran (SEM) 2,296; (3) berdasarkan hasil analisis metode cheating terdapat jumlah pasangan yang diduga melakukan cheating: Metode Angoff's B-index terdapat 13 pasangan, metode Pair 1 terdapat 212 pasangan, metode Pair 2 terdapat 444 pasangan, metode MESA terdapat 7 pasangan, dan metode $G 2$ terdapat 102 pasangan yang terdeteksi cheating; (4) berdasarkan hasil analisis, metode yang lebih banyak mendeteksi adanya cheating dalam Ujian Nasional Kimia secara berturutturut adalah metode Pair 2, metode Pair 1, metode G2, metode Angoff's B-index dan metode MESA.

Saran

Berdasarkan hasil penelitian, disarankan beberapa hal yang berkaitan dengan perangkat Ujian Nasional Kimia Paket C72 SMA/MA Negeri di Provinsi Maluku sebagai berikut: (1) agar dapat memenuhi standar perangkat tes yang baik dalam upaya mengestimasi kemampuan peserta tes, maka pada perakitan perangkat tes dan ujicoba di waktu mendatang Dinas Provinsi perlu mengusulkan ke Pemerintah Pusat agar pelaksanaan ujicoba soal Ujian Nasional perlu dilaksanakan juga pada daerah-daerah yang sulit/jauh dari pusat; (2) sekolah dan guru perlu menanamkan sikap kejujuran kepada setiap peserta didik dalam menghadapi Ujian Nasional sebab praktik-praktik cheating bukanlah alternatif yang baik dalam mendongkrak nilai Ujian Nasional dari sekolah melainkan dengan melakukan dan melaksanakan sistem pembelajaran yang baik, metode pengajaran yang tepat dan efektif sehingga semuanya itu akan menjadi solusi yang positif untuk peserta didik; (3) dalam mendeteksi adanya perilaku cheating yang berdampak negatif pada dunia pendidikan, maka perlu dikembangkan metode cheating yang tepat berdasarkan kriteria yang baik sehingga data yang diperoleh lebih akurat.

Analisis Metode Cheating pada Tes Berskala Besar - 127

Yance Manopo, Djemari Mardapi 


\section{Daftar Pustaka}

Anderman, E. M., Griesinger, T., \& Westerfield, G. (1998). Motivation and cheating during early adolescence. Journal of Educational Psychology. 90, 84-93.

Anderman, E. M., Pamela, K. C., \& Derek, L. (2010). Impulsivity and academic cheating. Journal of Educational Psychology. 90, 84-93.

Aziz, Deden Abdul. (September 2012). Soal Ujian Nasional SMP Diduga Bocor. Tempo Online diakses pada tanggal 30 September 2012, dari: http://www. tempo.co/read/news

Bogle, K. D. (2000). Effect of perspective, type of student, and gender on the attribution of cheating. Proceedings of Oclahoma Academic Science. Oclahoma City, 80, 91-97.

Chula, G. K., Roger, W.G., \& Chris, P. (2009). Online exams and cheating: an empirical analysis of business students' views. The Journal of Educators Online, 6, 1.

Cizek, G. J. (1999). Cheating on tests: How to do it, detect it, and prevent it. Mahwah, New Jersey: Lawrence Erlbaum.

(April 2001). An overview of issues concerning cheating on largescale tests. Paper presented at the annual meeting of the National Council on Measurement in Education, in Seattle, WA.

Depdiknas (2003). Undang-Undang RI Nomor 20, Tahun 2003, tentang Sistem Pendidikan Nasional.

.(2005). Peraturan Pemerintah RI Nomor 19, Tahun 2005, tentang Standar Nasional Pendidikan.

Eisenberg, J. (2004). To cheat or not cheat: effects of moral perpective and situational variables on students' attitudes. Journal of Moral Education, 33, 2, 163 178.
Hambleton, R. K., \& Swaminathan, H. (1985). Item response theory: principles and applications. Boston, MA: Kluwer Academic Publishers.

Lama, M. Al. (2008). Student's attitudes toward cheat and relation to demographyc factors. European Journal of Social Science. 7, 1, 140-146.

Lewkowicz, A. B. (2007). Teaching emotional intelligence, California: Corwin Press.

Lim, V. K. G., Sean, K. B. S. (2001). Attitudes toward, and intentions to report, academic cheating among students in Singapure. Ethnic \& Behavior, Lawrence Erlbaum Associates, 11(3), 261-274

Mardapi, Djemari. (1999). Estimasi kesalahan pengukuran dalam bidang pendidikan dan implikasinya pada ujian nasional. Yogyakarta: UNY.

McCabe, D. L., Linda K. T., \& Kenneth, D.B. (2001). Cheating in academic institutions: a decade of research. Ethnic \& Behavior, 11(3), 219-232.

Shapiro, E. S. (2011). Academic skill problems (4th Ed.). New York: The Guildford Press.

Strom, P. S., \& Strom R., D. (2007) Cheating middle school and high school. The Education Forum, 71, 104-116

Widiatmo, H. (2009). Metode untuk mendeteksi penyontekan jawaban pada tes pilihan ganda: studi kasus SMP di Kabupaten Garut. Pusat Penelitian Pendidikan, Balitbang Diknas. 219-226.

Williams, J. B. (2002). The plagiarism problem: are students entirely to blame. Proceedings of ASCILITE. Australia

Williams, K., M., Craig N., Delroy L.P. (2010). Identifying and profiling scholastic cheaters: their personality, cognitive ability, and motivation. Journal of Experimental Psycology. 16 (3), 293307. 